Available online on 15.07.2018 at http://jddtonline.info
Open Access to Pharmaceutical and Medical Research
commercial use, provided the original work is properly cited

Open $\odot$ Access

Research Article

\title{
BRINE SHRIMP LETHALITY BIOASSAY OF BOUGAINVILLEA GLABRA
}

\author{
*Sudheer K Dokuparthi, G. Lakshmi, A. Anjana, Syed F Fatima, P. Ashwini, Suresh Kandagatla, Suthakaran Raj \\ Vijaya College of Pharmacy, Munaganoor-501511, Hyderabad, Telangana, India
}

\section{ABSTRACT}

The crude methanolic extract of Bougainvillea glabra leaves has been investigated for the evaluation of the cytotoxic activity. All the extracts of the plant were screened for their cytotoxicity by using brine shrimp nauplii (Artemia salina) lethality bioassay. The toxicity was assessed in terms of $\mathrm{LC}_{50}$ (lethality concentration), 10 nauplii were taken into three replicates of each concentration of the methanolic leaf extract. Brine shrimps were checked for the mortality during 24 hrs period, surviving brine shrimps were counted and $\mathrm{LC}_{50}$ was evaluated. The results showed that all the extracts were showing potent toxicity to the nauplii. The $\mathrm{LC}_{50}$ values were compared to the standard potassium dichromate. It indicates that the extracts are toxic even at low doses. Further investigation is needed to study the acute and subacute toxicity of the extracts for its safe application to the humans.

Keywords: Artemia salina, cytotoxicity, Bougainvillea glabra, mortality

Article Info: Received 07 May, 2018; Review Completed 27 June 2018; Accepted 01 July 2018; Available online 15 July 2018

Cite this article as:

Dokuparthi SK, Lakshmi G, Anjana A, Fatima SF, Ashwini P, Kandagatla S, Raj S, Brine shrimp lethality bioassay of Bougainvillea glabra, Journal of Drug Delivery and Therapeutics. 2018; 8(4):244-246 DOI: http://dx.doi.org/10.22270/iddt.v8i4.1780

*Address for Correspondence:

Sudheer Kumar Dokuparthi, HOD, Department of Pharmacognosy, Vijaya College of Pharmacy, Munaganoor-501511, Hyderabad, Telangana, India.

\section{INTRODUCTION}

The brine shrimp lethality bioassay is a simple and rapid method to evaluate the cytotoxic activity. It inexpensive and requires small amounts of test materials ${ }^{1}$. The bioassay has a good correlation with pesticidal activity and with cytotoxic activity in solid tumors. This invivo lethality assay can be successively applied as a primary screening that can be backed up by more sophisticated and specific evaluation bioassays ${ }^{2}$.

Bougainvillea glabra is an ornamental shrub also called as a paper flower ${ }^{3}$. It is native to many tropical and subtropical areas like Middle East, North America, Brazil, India etc. The genus, Bougainvillea belongs to the family Nyctaginaceae ${ }^{4}$. Out of 18 species of the genus Bougainvillea glabra is one of the famous species. The leaves are generally having small hairs. The flowers are in very attractive combinations colors like white, red yellow, orange, violet and purple. The stems are thin, with repeated prickles ${ }^{5}$. Traditionally, the plant is used in a variety of ailments like ulcer, cough, diarrhea, hepatitis and as an expectorant. The leaves are having more extensive uses like anti diabetic ${ }^{6}$, anti viral ${ }^{7}$, anti inflammatory ${ }^{5}$, anti microbial ${ }^{8}$, antifertility properties ${ }^{3}$.

Our, present study is to investigate the toxicity of the plant leaf by brine shrimp lethality bioassay. The methanolic leaf extract was prepared by Soxhlet method and this extract was used for the further studies.

\section{MATERIALS AND METHODS}

\section{Collection of plant material}

The fresh plant was collected during the month of September, 2017 from Hayathnagar rural area, Hyderabad. The plants were authenticated and specimens have been deposited in the college museum. The fresh leaves were shade dried at room temperature. The dried seeds then subjected to size reduction by the cutter type electric mill to get a coarse powder.

\section{Extraction of plant materials}

The coarse powder of the plant material was then subjected to hot exhaustive percolation method by using Soxhlet apparatus. The Soxhlet extraction was performed by the use of different solvents starting with 
nonpolar to polar solvents (n-Hexane, Ethyl acetate, and methanol respectively). The extraction was progressed around 4-6 cycles per hour for $24 \mathrm{hrs}$. Then each of the extracts was filtered using cotton plugs followed by Whatmann No. 1 filter paper. The filtrates were then concentrated and dried under reduced pressure in the rotary evaporator. The percentage yield was found to be $10.5 \%$. The extracts were stored in airtight container in the refrigerator for future analysis.

\section{Preliminary phytochemical screening}

Preliminary phytochemical screening of the plant extracts was done by the standard procedures ${ }^{9,10}$. The results are illustrated in Table 1.

\section{Hatching of brine shrimp}

The eggs of brine shrimp were procured from the local market and hatched in a glass compartment with sea water. The glass compartment is having two partitions, one is illuminated. After $24 \mathrm{hrs}$ of hatching at room temperature, the eggs hatch into larvae (nauplii), which will swim towards the illumination chamber by leaving their shells in the dark chamber. The nauplii were collected carefully by pipette for the bioassay.

\section{Preparation of test samples}

$32 \mathrm{mg}$ of each of the test samples were taken and dissolved in $200 \mu \mathrm{l}$ of pure dimethyl sulphoxide (DMSO). The final volume was made to $20 \mathrm{ml}$ with sea water. The concentration of the stock solution is 1600 $\mu \mathrm{g} / \mathrm{ml}$. Eight samples of volume $5 \mathrm{ml}$ having different concentration $1600,1000,800,500,250,100,50,25$ $\mu \mathrm{g} / \mathrm{ml}$ were prepared by diluting the stock solution with sea water.

\section{Control group}

This group is used to validate the test method and ensure that the cytotoxicity is only due to the activity of the test compounds. Two types of control groups were used in this experiment- Potassium dichromate $(200 \mu \mathrm{g} / \mathrm{ml})$ as the positive control and $50 \mu \mathrm{g} / \mathrm{ml}$ of DMSO in $4.95 \mathrm{ml}$ of sea water as the negative control.

\section{Brine shrimp assay}

To the pre-marked vials containing above-prepared concentrations, 10 nauplii were added. After $24 \mathrm{hrs}$, the nauplii in each vial were counted with the aid of a $3 x$ magnifying glass for the surviving brine shrimp. The mortality endpoint of this bioassay is the absence of controlled forward motion during the 30 s of observation. These results were depicted in Table 2 .

\section{RESULTS AND DISCUSSIONS}

Preliminary phytochemical screening

The preliminary phytochemical screening of the methanol leaf extract of Bougainvillea glabra revealed the presence of various secondary metabolites which are illustrated in Table 1.

Table 1: Preliminary phytochemical screening of various extracts of Bougainvillea glabra leaf

\begin{tabular}{|l|c|c|c|}
\hline Phytochemicals & n-Hexane extract & Ethylacetate extract & Methanol extract \\
\hline Alkaloids & + & - & + \\
\hline Glycosides & + & + & + \\
\hline Terpenoids & + & + & + \\
\hline Steroids & + & + & + \\
\hline Saponins & + & + & + \\
\hline Flavonoids & + & + & + \\
\hline Tannins & - & - & - \\
\hline Carbohydrates & - & - & - \\
\hline Lipids & - & - & \\
\hline Proteins & - & & \\
\hline
\end{tabular}

\section{Brine shrimp lethality assay:}

Brine shrimp nauplii are simple zoological organisms which can be used to evaluate the lethality ${ }^{11}$. It is a simple and very useful tool to screen diverse compounds. This bioassay is also used to screen plant extracts. It is a safe, economical method for determination of the cytotoxicity of synthetic and plant products $^{12}$. The bioassay can be correlated significantly to the inhibition of human solid tumor cell lines. It is the primary tool to detect the anti-tumor properties ${ }^{13}$. The toxicity of plant extracts can be evaluated by their $\mathrm{LC}_{50}$ values. If $\mathrm{LC}_{50}$ values are lower than $1000 \mu \mathrm{g} / \mathrm{ml}$ is considered as cytotoxic ${ }^{11}$. This bioassay can also be used for the evaluation of antifungal, teratogenic effect, pesticidal effect and environmental toxicity ${ }^{14}$. The brine shrimp bioassay results illustrated in Table 2. In this study, it was observed that n-Hexane, Ethyl acetate, and methanolic extracts were toxic to the brine shrimps nauplii. They exhibit potent toxicity, compared to the standard potassium dichromate. For n-Hexane, Ethyl acetate, and methanolic extracts respectively. The relation of toxicity of the extract to the nauplii was found to be directly proportional from low to high (25 $\mu \mathrm{g} / \mathrm{ml}$ to $1600 \mu \mathrm{g} / \mathrm{ml})$. Concentrations of the extracts ranging from lowest concentration $(25 \mu \mathrm{g} / \mathrm{ml})$ to highest concentration $(1600 \mu \mathrm{g} / \mathrm{ml})$. The presences of components like alkaloids, steroids, saponins, and tannins which are already reported to have the cytotoxic property are responsible for the reported activity in a dose dependant manner. 
Table 2: Mean percentage of mortality of Artemia salina brine shrimp after $24 \mathrm{hrs}$ at different concentrations of the Bougainvillea glabra leaf extracts.

\begin{tabular}{|l|l|l|l|l|l|l|l|l|l|}
\hline \multirow{2}{*}{ Extract } & \multicolumn{9}{|l|}{ Mean \% of mortality at concentration $(\mu \mathrm{g} / \mathrm{ml})$} \\
\cline { 2 - 11 } & Negative control & 25 & 50 & 100 & 250 & 500 & 1000 & 1600 & Positive control \\
\hline n-Hexane & $\mathbf{0}$ & $\mathbf{2 1}$ & $\mathbf{4 0}$ & $\mathbf{6 0}$ & $\mathbf{7 0}$ & $\mathbf{8 5}$ & $\mathbf{9 9}$ & $\mathbf{1 0 0}$ & $\mathbf{1 0 0}$ \\
\hline Ethyl acetate & $\mathbf{0}$ & $\mathbf{2 5}$ & $\mathbf{4 5}$ & $\mathbf{6 2}$ & $\mathbf{7 4}$ & $\mathbf{8 9}$ & $\mathbf{9 7}$ & $\mathbf{1 0 0}$ & $\mathbf{1 0 0}$ \\
\hline Methanol & $\mathbf{0}$ & $\mathbf{2 8}$ & $\mathbf{4 7}$ & $\mathbf{6 8}$ & $\mathbf{7 7}$ & $\mathbf{8 1}$ & $\mathbf{1 0 0}$ & $\mathbf{1 0 0}$ & $\mathbf{1 0 0}$ \\
\hline
\end{tabular}

\section{CONCLUSION}

From the above study, it is observed that the methanolic leaf extract of Bougainvillea glabra exhibited cytotoxicity against the brine shrimp nauplii. The $\mathrm{LC}_{50}$ values are found to be less than $1000 \mathrm{mg} / \mathrm{ml}$. It may be due to the presence of bioactive components. This bioassay can only give information that it is having very potent biologically active components. But, this assay is inadequate to understand the mechanism of action of the phytochemicals present in it. Further investigations are needed in isolation, structure elucidations of the phytochemicals present in the leaf of Bougainvillea glabra and toxicity towards the cell lines will help us to understand its molecular mechanism of their bioactivity.

\section{ACKNOWLEDGMENT}

Authors are thankful to the management of Vijaya College of Pharmacy, for providing necessary facilities.

\section{CONFLICT OF INTEREST}

Authors do not have any conflict of interest

\section{REFERENCES}

1. Ghisalberti EL. Detection and isolation of bioactive natural products. In: Colegate SM, Molyneux RJ, editors. Bioactive natural products: Detection, isolation and structure elucidation. New York: CRC Press; 1993. p. 15-8.

2. McLaughlin JL, Rogers LL, Anderson JE. The use of biological assays to evaluate botanicals. Drug Inform J 1998; 32:513-24.

3. Mishra N., Joshi S, Tandon VL, Munjal A. Evaluation of antifertility potential of aqueous extract of Bougainvillea spectabilis leaves in Swiss albino mice. Int. J. Pharm. Sci. Drug Res., 2009; 1:19-23.

4. Bhat M., Kothiwale S.K., Tirmale A.R., Bhargava S.Y., Joshi B.N., Antidiabetic properties of Azardirachta indica and Bougainvillea spectabilis: In vivo studies in murine diabetes model. Evid.-Based Complement. Altern. Med., Vol. 2011. 10.1093/ecam/nep033

5. Adebayo J.O., Adesokan A.A., Olatunji L.A., Buoro D.O., Aoladoye A.O., Effect of ethanolic extract of Bougainvillea spectabilis leaves on haematological and serum lipid variables in rats. Biokemistri, 2005; 17:45-50.

6. Saikia H., Lama A, Effect of Bougainvillea spectabilis leaves on serum lipids in albino rats fed with high-fat diet. Int. J. Pharm. Sci. Drug Res., 2011; 3:141-145.

7. Bolognesi A., Polito L, Olivieri F, Valbonesi P, Barbieri L et al., New ribosome-inactivating proteins with polynucleotide: adenosine glycosidase and antiviral activities from Basella rubra L. and Bougainvillea spectabilis Willd. Planta, 1997; 203:422-429.

8. Edwin E., Sheeja E, Toppo E, Tiwari V, Dutt KR, Antidiarrhoeal, anti ulcer and antimicrobial activities of leaves of Bougainvillea glabra Choisy. Ars Pharmaceutica, 2007; 48:135-144.

9. Sofowara A. Medicinal plants and traditional medicine in Africa. Spectrum Books Ltd., Ibadan: Nigeria. 1993, 289-300.

10. Harborne JB. Phytochemical Methods. Chapman and hall Ltd., London: U.K., 1973, 49-188.

11. Meyer BN, Ferrigni NR, Putnam JE, Jacobsen LB, Nichols DE, McLaughlin JL. Brine shrimp: A convenient general bioassay for active plant constituents. Planta Medica 1982; 45:31.

12. Almeida PA, Silva TMS, Echevarria A. Mesoionic 5-alkyl1,3-dithiolium-4-thiolates: Synthesis and brine shrimp toxicity. Heterocycl Comm 2002; 8:593-600.

13. Anderson JE, Goetz CC, McLaughlin JL, Sufness M, A blind comparison of simple bench-top bioassays and human tumor cell cytotoxicities as antitumor prescreens. Phytochem Analysis, 1991; 2:107-111.

14. Vanhaecke P. \& Sorgeloos P., International Study on Artemia. 14. Growth and survival of Artemia larvae of different geographical origin in a standard culture test. Mar. Ecol. Prog. Ser. 1980b; 3:303-307. 